\title{
THE COMBINED USE OF FIVE BACTERIA INCLUDING BACILLUS AMYLOLIQUEFACIENS Y1 AS BIOFERTILIZER IN COMPOST IMPROVED LOW BUSH BLUEBERRY GROWTH, RHIZOSPHERE BACTERIA AND ENZYME AT VARIOUS pH
}

\author{
Qaiser Jamal $^{1, *}$, Yong Seong Lee ${ }^{3}$, Shahzad Munir ${ }^{2}$ Muhammad Saqib Malik ${ }^{1,}$ and \\ Kil Yong Kim ${ }^{3, *}$ \\ ${ }^{1}$ Department of Microbiology, Kohat University of Science and Technology, Kohat, Pakistan; \\ ${ }^{2}$ Faculty of Plant Protection, Yunnan Agricultural University, Kunming 650201, Yunnan, China; \\ ${ }^{3}$ Division of Food Technology, Biotechnology and Agrochemistry, Institute of Environmentally-Friendly \\ Agriculture, Chonnam National University, Gwangju 61186, South Korea. \\ *Corresponding author's e-mail: qaiserjamal71@yahoo.com; kimkil@jnu.ac.kr
}

\begin{abstract}
The present study was performed to investigate blueberry compost material alternative to commercially available one mainly containing peat moss and evaluate its potential in pot experiment using five bacteria. Initially, we divided our made compost (M) into three types based on $\mathrm{pH}\left(4.5,5.5\right.$ and 7) using $\mathrm{H}_{2} \mathrm{SO}_{4}$. In physiochemical analysis, each type of $\mathrm{M}$ was found to have different composition of $\mathrm{N} \mathrm{P}, \mathrm{Ca}, \mathrm{Mg}, \mathrm{Mn}$ and $\mathrm{S}$ and higher than commercial compost. Our results indicate negative effects of acidification on bacterial population, diversity and activities of protease, chitinase, and cellulase in $\mathrm{M}$ compost. In blueberry pot experiment, plants were grown in $4.5 \mathrm{M}, 5.5 \mathrm{M}, 4.5 \mathrm{C}$ and $7 \mathrm{M}$. Two types of treatments were performed including chemical fertilizer (F) and the other type contained bacterial culture (C) including B. amyloliquefaciens Y1, B. licheniformis MH48, B. pumilus L1, P. ehmensis KWN38 and P. elgii HOA73 grown together in broth containing chitin powder. The use of biofertilizers significantly increased plant biomass compared to all fertilizer treatments and $\mathrm{pH} 7 \mathrm{M}$ treated with bacterial culture (C) has highest value among all treatments. Inoculation of bacteria not only increased total number and type of bacteria but also improved chitinase and gelatinase in rhizosphere of blueberry plants. These results suggest that our made compost can be used as blueberry compost and inoculation of five bacteria have positive effects on blueberry growth, bacterial population and enzyme activities in compost at various $\mathrm{pH}$.

Keywords: Compost, blueberry, biofertilizers, crab shell powder, bacteria, chitinase.
\end{abstract}

\section{INTRODUCTION}

Blueberry production worldwide increased $30 \%$ between 1992 and 2003, tracking an increase in consumer demand (Strik and Yarborough, 2005). The blueberry is an ericaceous plant adapted to well-drained soils that are high in organic matter, with a preferred soil $\mathrm{pH}$ range of 4.5-5.5 (Haynes, 1986; Gough, 1993). These adoptability criteria effectively limit its growth suitable sites for commercial production to specific geographical regions (Eck and Childers, 1966; Pritts et al., 1992). Due to these limitations, number of research efforts have been attempted to investigate to improve soil properties. In this regard, compost may provide an alternative source, containing high content of organic matter. However, blueberry growth is predominated to grow at low $\mathrm{pH}$, due to which other factors affected positively or negatively. The properties like physiochemical, biological and biochemical dependently varies with $\mathrm{pH}$ of compost. The indigenous microbes in the compost material can decompose the organic matter, and transformation of $\mathrm{N}$ component through oxidation, nitrification and denitrification (Atkinson et al., 1996; Tiquia et al., 2002). Changes in $\mathrm{pH}$ level during the bioconversion also inhibit metabolic activity of microorganisms (Wong et al., 1995). The short-chain organic acids are predominantly present in their un-dissociated forms at low $\mathrm{pH}$, which are toxic to microorganisms.

Microbial population and its activities in soil are often measured as soil enzyme activities (Frankenberger and Dick, 1983). It is also well known that enzymes catalyzed all biochemical reactions during composting (Godden et al., 1983: Garcia et al., 1992; Vuorinen, 2000). Acidification of soil reduces rhizosphere bacterial population which indirectly causes decline in enzyme activities. To understand the composting process, the changes of different microbial populations such as bacteria, actinomycetes, and fungi would be helpful. Enzymes involved in carbon $(\mathrm{C})$, nitrogen $(\mathrm{N})$, and phosphorus (P) cycles are also affected by $\mathrm{pH}$ of the composting substrates (Kapoor and Rajagopal, 2011). Therefore, the qualitative and quantitative changes which occurred after acidification is important criteria that should be 
evaluated. Rhizosphere-inhabiting microorganisms interact with the root system and with each other to influence plant growth and productivity. In this regard, addition of plant growth-promoting rhizobacteria (PGPR) or addition of specific substrate plays an important role to stimulate promotion of indigenous microbes to minimize the limitation of compost acidification processes.

The addition of PGPR is widely used in modern agriculture to overcome stress condition and helps the plants with an increase in growth and yield. The PGPR benefit plants through different modes of action, including, (i) phosphate solubilization, (ii) dinitrogen fixation, (iii) siderophores production, (iv) antagonism to soil borne root pathogen producing secondary metabolites such as antibiotics (v) Lytic enzymes production, (vi) inducing systemic resistance (Kumar and Narula, 1999). Many of the documented PGPR are members of Rhizobium, Azotobacter, Pseudomonas, Bacillus and Azospirillium (Antoun and Kloepper, 2001). The genus Bacillus is widely studied as PGPR due to their best characterized root colonization ability and sporulation ability. Inoculation of Bacillus spp. in soil as PGPR can solubilize fixed soil $\mathrm{P}$ and increase inorganic $\mathrm{P}$ availability to plant (Kumar and Narula, 1999) resulting higher crop yields (Yadav and Dadarwal, 1997; Puente et al., 2004). Many strains of Bacillus subtilis, Bacillus amyloliquefaciens, Bacillus cereus (Choudhary and Johri, 2009), B. licheniformis CECT5106 and B. pumilus CECT5105 (Probanza et al., 2002), Paenibacillus elgii HOA 73 (Nguyen et al., 2013) and Paenibacillus ehmensis KWN38 (Naing et al., 2014) have been found to interact with plants and produce beneficial effects including plant growth promotion and disease suppression

In this study, attempts were made to formulate compost for blueberry plants growth. The formulated compost was further investigated for growing blueberry plants at various $\mathrm{pH}(4.5$, 5.5 and 7) using five bacteria including Bacillus amyloliquefaciens Y1, Bacillus licheniformis MH48, Bacillus pumilus L1, Paenibacillus ehmensis KWN38 and Paenibacillus elgii HOA73 in comparison to commercial compost ( $\mathrm{pH} \mathrm{4.5)}$ and plant growth was investigated. These isolates were selected on the basis of plant growth promoting abilities in our previous studies.

\section{MATERIALS AND METHODS}

Experiment material: In this study, mainly two types of compost were used. One type, we made from mixing wood crust, peat moss, vermiculite, organic matter, crab shell powder, micronutrients and sulfur powder having $\mathrm{pH} 7.0 \pm 0.3$ (M), while other compost was commercial compost mainly containing peat moss ( $\mathrm{pH} 4.5)$. Our made compost (M) was divided into three parts on the basis of $\mathrm{pH}$ difference (5.5 and 4.4) using $\mathrm{H}_{2} \mathrm{SO}_{4}$ while one part was kept at its initial $\mathrm{pH}$
$7 \pm 0.3$. The made compost was kept in close container at room temperature for one month before observations.

The five bacteria used in blueberry pot experiment as biofertilizers including $B$. amyloliquefaciens $\mathrm{Y} 1, \quad B$. licheniformis $\mathrm{MH} 48$, B. pumilus L1, P. ehmensis KWN38 and $P$. elgii HOA73 were isolated in our previous studies and registered at NCBI with accession number of KP967704, KP099612, KJ206069, JN050969 and JQ412069, respectively. Total of 100 blueberry plants of $20-30 \mathrm{~cm}$ (shoot) height were obtained from a commercial nursery grown in nursery media containing peat and pine bark.

Physiochemical analysis: The Bulk density, volumetric water content, gravitational water content and gravitational density of compost were analyzed. The $\mathrm{pH}$ and electrical conductivity (EC) of composts were measured in a 1:5 (compost: water) aqueous extract. Total nitrogen content in compost was determined by sulfuric acid digestion using $\mathrm{CuSO}_{4}$ and $\mathrm{K}_{2} \mathrm{SO}_{4}$ as catalyst in the Kjeldhal method. Total organic-C was determined as described by Walkley and Black (1934). The composts were finally assessed for P, K, Ca, Mg and $\mathrm{S}$ using inductively coupled plasma (ICP) spectrophotometer. All observations were carried out in triplicate and each assessment was performed three times.

\section{Compost maturity}

Total number of bacteria in compost: Total number of bacteria and chitinase producing bacteria were counted in each type of compost before pot experiment. In order to find out total number of bacteria, ten grams of compost was poured into the flask containing $100 \mathrm{~mL}$ of autoclaved distilled water, serially diluted and poured on LB (Laurie Britannia) agar plate. For isolation of chitinase producing bacteria, colloidal chitin was prepared by method of Monreal and Reese (1969) from chitin flakes (Samsung Chitopia Co. Korea). The compost samples were diluted serially and $100 \mu \mathrm{l}$ from each sample was spread on chitin agar medium containing $0.5 \%$ swollen chitin (prepared from chitin $0.2 \% \mathrm{Na}_{2} \mathrm{HPO}_{4}, 0.1 \%$ $\mathrm{K}_{2} \mathrm{HPO}_{4}, 0.05 \% \mathrm{NaCl}, 0.1 \% \mathrm{NH}_{4} \mathrm{Cl}, 0.05 \% \mathrm{MgSO}_{4} \cdot 7 \mathrm{H}_{2} \mathrm{O}$, $0.05 \mathrm{CaCl}_{2} \cdot 2 \mathrm{H}_{2} \mathrm{O}, 0.01$ yeast extract and $1.8 \%$ agar $(\mathrm{pH} 7)$. The plates were incubated at $30^{\circ} \mathrm{C}$ for 5 days. All colonies which showed the clear zone around their colonies were counted. The microbial populations were counted and expressed as $\log 10 \mathrm{CFU}$ number per $\mathrm{g}$ of dry compost.

Biochemical assessment: The activity of three different microbial enzymes - cellulase, protease and chitinase were measured in each compost sample before pot experiment. Protease and cellulase activities were measured based on a method described by Alef and Nannipieri (1995). Chitinase activity in compost was determined using the modified method of Tabatabai (1982) and Yedidia et al. (2000). Briefly, the compost $(0.5 \mathrm{~g})$ was added to a test tube containing $0.25 \mathrm{ml}$ of toluene, $4.0 \mathrm{ml}$ of $50 \mathrm{mM}$ sodium acetate buffer ( $\mathrm{pH} 5.0$ ), and $1.0 \mathrm{ml}$ of $0.5 \%$ colloidal chitin and incubated at $37^{\circ} \mathrm{C}$ for $2 \mathrm{~h}$. After incubation, $1.0 \mathrm{ml}$ of 0.5 $\mathrm{M} \mathrm{CaCl}_{2}$ and $4.0 \mathrm{ml}$ of $0.5 \mathrm{M} \mathrm{NaOH}$ were added to the mixture 
thoroughly and centrifuged at $10,000 \mathrm{~g}$ for $10 \mathrm{~min}$. The supernatant was filtered through Whatman No. 2 filter paper. Schales' reagent $(1 \mathrm{ml})$ was added to $0.75 \mathrm{ml}$ of the filtrate, and the reaction was then initiated by heating in boiling water for $15 \mathrm{~min}$. Chitinase activity was calculated by measuring the concentration of N-acetyl-glucosamine at $420 \mathrm{~nm}$.

Blueberry pot experiment: Total of 100 blueberry plants of $20-30 \mathrm{~cm}$ (shoot) height were obtained from a commercial nursery and transplanted into $20 \mathrm{~L}$ pots on Jan 2015. Experiment was performed in complete random block design with 10 for each treatment and experiment was performed in an open environmental condition. Nursery media, which contained peat and pine bark, was not removed from the plants during transplanting to limit root damage. Blueberry plants were grown for 7 months and then harvested for observation.

Treatment preparation: Two types of treatment were performed after every 30 days. In one type of treatment, blueberry plants were treated with fertilizer containing $\mathrm{CaMg}$ $0.5 \mathrm{~g}$, sulfur $0.02 \mathrm{~g}$, micronutrients $0.01 \mathrm{~g}$ and complex fertilizer $0.5 \mathrm{~g}$ per $100 \mathrm{ml}$. In second type, $100 \mathrm{~L}$ of bacterial culture was prepared by growing $B$. amyloliquefaciens Y1, B. licheniformis MH48, B pumilus, $P$. ehmensis KWN38 and $P$. elgii $\mathrm{HOA} 73$ at $40^{\circ} \mathrm{C}$ in broth containing crab shell $0.1 \mathrm{~g}$, gelatin $0.05 \mathrm{~g}, \mathrm{CaMg} 0.5 \mathrm{~g}$, sulfur $0.02 \mathrm{~g}$, micronutrients $0.01 \mathrm{~g}$, complex fertilizer (NPK) $0.5 \mathrm{~g}$ and sugar $0.5 \mathrm{~g}$ per $100 \mathrm{ml}$. Before inoculation in pot, treatment (culture and fertilizer) $\mathrm{pH}$ was adjusted according to prescribed $\mathrm{pH}$ value of pot compost $(4.5,5.5$ and 7$)$ and each pot was amended with 1 liter of culture/ fertilizer. Total of five treatments were given after every 30 days.

Plant observations: Blueberry plants were harvested after 7 months. After harvesting, plants were randomly but carefully uprooted to get the sample roots. The plants roots were washed gently under running tap water and dried. The plants were divided into shoots and roots, and used to measure shoot fresh weight, root fresh weight, total chlorophyll, total numbers of leaves, leaf weight and leaf area.

Total number of bacteria in Compost: After harvesting plants, compost material was observed for total number of bacteria and chitinase producing bacteria. Total number of bacteria and chitinase producing bacteria were calculated as mentioned above before pot experiment.
Chitinase and gelatinase in compost: After harvesting plants, chitinase and gelatinase activity in soil were determined. Chitinase activity was determined using the modified method of Tabatabai (1982) and Yedidia et al. (2000) while gelatinase was assayed based on the method of Ladd and Butler (1969). Statistical analysis: The data were analyzed by using the Statistical Analysis System 9.1 (SAS, 2002) program to calculate standard deviation and significance of difference at $P<0.05$.

\section{RESULTS}

Physiochemical properties of compost: Physical properties like Bulk density, volumetric water content, gravitational water content and gravitational density were not significantly different in $\mathrm{M}$ of various $\mathrm{pH}$ ( $\mathrm{pH} 4.5, \mathrm{pH} 5.5$, and $\mathrm{pH}$ 7) (Table 1). The EC increased with application of $\mathrm{H}_{2} \mathrm{SO}_{4}$. Acidification of composts can remedy high $\mathrm{pH}$, but the byproduct of the process is $\mathrm{SO}_{4}{ }^{-}$, which increases compost salinity and as result EC increased. No clear trend was observed in the total $\mathrm{N}$ levels but was found more in all type of $\mathrm{M}$ compost compared to commercial compost. Total organic matters were found more in commercial compost compared to made compost. Phosphorus is also a major nutrient for plants and microorganisms. Available $\mathrm{P}$ in compost material was decreased with the application of sulfuric acid as $\mathrm{pH} 7 \mathrm{M}$ has high concentration than $\mathrm{pH} 4.5 \mathrm{M}$ and $\mathrm{pH}$ 5.5 M. All types of $\mathrm{M}$ were found to have more elements like $\mathrm{P}, \mathrm{Ca}, \mathrm{Mg}, \mathrm{Mn}$ and $\mathrm{S}$ compared to commercial compost while $\mathrm{M}$ compost of various $\mathrm{pH}$ has different concentrations as shown in Table 1.

Number of bacteria: A significant adverse effect of $\mathrm{H}_{2} \mathrm{SO}_{4}$ was found on bacterial population in $\mathrm{pH} 4.5 \mathrm{M}$ and $\mathrm{pH} 5.5 \mathrm{M}$ (Fig. 1). Total bacterial colony forming in $\mathrm{pH} 7 \mathrm{M}$ was significantly higher than that of $\mathrm{pH} 4.5 \mathrm{M}, \mathrm{pH} 5.5 \mathrm{M}$ and $\mathrm{pH}$ $4.5 \mathrm{C}$ before transplantation of blueberry plants. The $\mathrm{pH} 4.5$ $\mathrm{C}$ has lowest number of bacterial CFU in all treatments. The MC 7 was also observed to have the highest number of chitinase producing bacteria in all treatments while $\mathrm{pH} 4.5 \mathrm{C}$ has the lowest CFU compared to all treatments.

Biochemical assessment of compost: As a diagnostic approach, enzyme activity is used to evaluate compost fertility or in predicting crop production. In our study, we observed a significant decline in the activity of all enzymes in compost after addition of sulfuric acid in $\mathrm{M}$ compost (Fig. 2A,

Table 1. Physiochemical properties of composts.

\begin{tabular}{lcccccccc}
\hline Treatments & EC $\left(\mathbf{d S m}^{-\mathbf{1}}\right)$ & T-N (\%) & OM (\%) & P (\%) & K (\%) & Ca (\%) & Mg (\%) & S (\%) \\
\hline pH 4.5 (M) & 2.8 & 0.625 & 30.4 & 1.49 & 0.45 & 2.4 & 1.5 & 0.18 \\
pH 5.5 (M) & 2.6 & 0.623 & 35.5 & 1.49 & 0.52 & 2.53 & 1.42 & 0.22 \\
pH 4.5 (C) & 0.02 & 0.427 & 41.8 & 0.05 & 0.21 & 0.24 & 0.47 & 0.03 \\
pH 7 (M) & 1.5 & 0.658 & 31.8 & 2.00 & 0.44 & 2.05 & 1.07 & 0.37 \\
\hline
\end{tabular}

$\mathrm{EC}=$ Electrical Conductivity, $\mathrm{TN}=$ Total Nitrogen, $\mathrm{OM}=$ Organic Matter, $\mathrm{MC}=$ Made compost, $\mathrm{C}=$ Commercial compost. ${ }^{*}$ Analysis

for Made compost was performed after one month of changing $\mathrm{pH}^{*}$ 
2B, 2C). Microbial biomass and enzymes have significant correlation with application of $\mathrm{H}_{2} \mathrm{SO}_{4}$ as $\mathrm{pH}$ declined. The chitinase and protease activities were found more in $\mathrm{pH} 7 \mathrm{M}$ while cellulase was found more in $\mathrm{pH} 4.5 \mathrm{C}$ as compared to all treatments. These negative correlations with enzymes activities indicate that as $\mathrm{pH}$ decreased the number of bacteria reduced, which indirectly affecting enzymes activity.

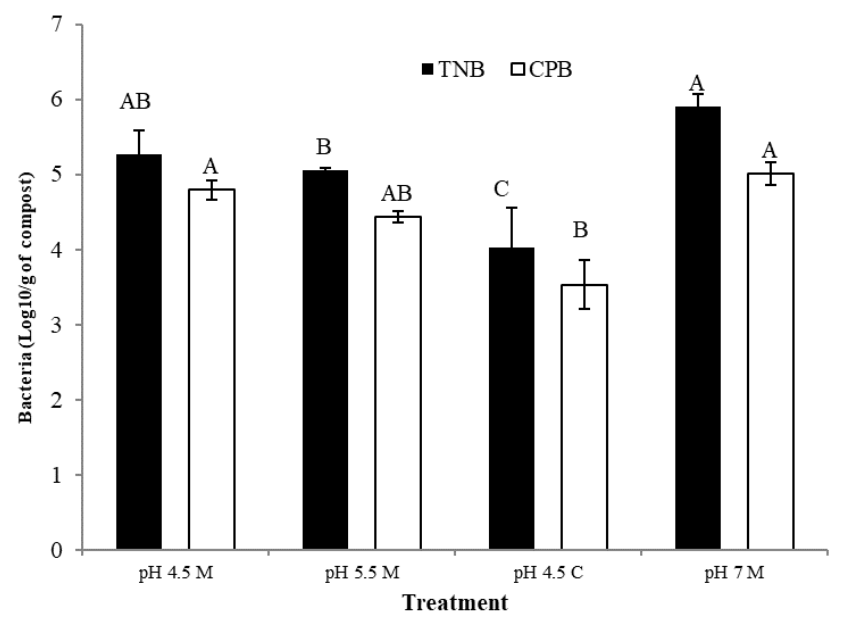

Figure 1. Total number of bacteria (TNB) and chitinase producing bacteria (CPB) colonies on Chitin agar plate found in various compost treatments before transplantation of blueberry plants. $\mathrm{M}=$ Made compost, $\mathrm{C}=$ Commercial compost, $\mathrm{TNB}=$ Total number of bacteria, $\mathrm{CPB}=$ Chitinase producing bacteria.

Plant growth assay: In blueberry pot experiment, incorporation of microorganisms in plants grown for seven months has increased plant weight compared to fertilizer treatment (Fig. 3). The shoot weights in all treatments of bacterial culture were observed more compared to fertilizer treatments. The fresh root weight was found the highest in $\mathrm{pH}$ 4.5 followed by $\mathrm{pH} 5.5 \mathrm{MC}$ while $\mathrm{pH} 7 \mathrm{MF}$ has the lowest value than all treatments. Shoot length was found significantly higher of blueberry plants grown in compost of
pH 7 M (70.6 \pm 4.8$)$ amended with microorganisms (Table 2). Total chlorophyll was found very low in $\mathrm{pH} 5.5 \mathrm{MF}$ followed by pH5.5 CF, pH $7 \mathrm{MF}$, pH 5.5CC, pH 4.5 MF, pH 4.5MC and $\mathrm{pH} 7 \mathrm{MC}$. In our study, like shoot and root, leaf was also affected with significant difference using microbial culture treatment to grow blueberry as compare to fertilizer treatment. Moreover, $\mathrm{pH}$ was also affecting leaf as $\mathrm{pH} 4.5 \mathrm{MF}$ have high leaf area , total number of leaves and leaf weight (fresh and dry) as compare to other fertilizer treatments. However, $\mathrm{pH}$ $7 \mathrm{MC}$ has the highest number of values in leaf study (number of leaves, leaf area $\left(\mathrm{cm}^{2}\right)$, leaf fresh weight $(\mathrm{g})$ and dry weight (g).
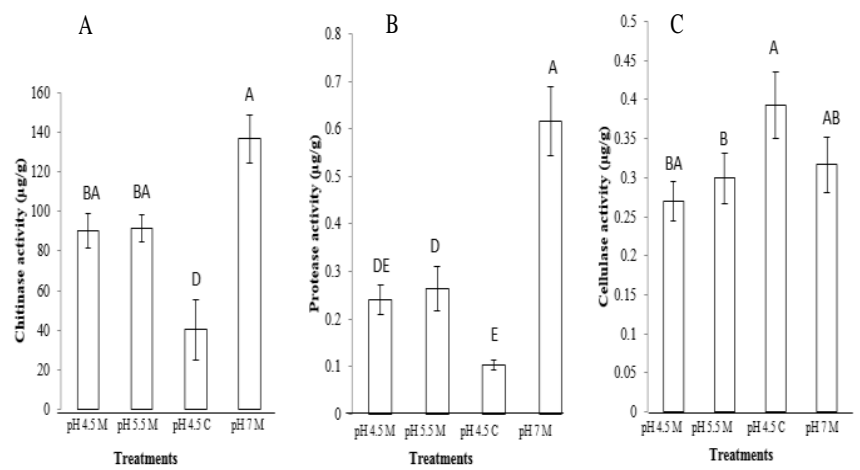

Figure 2.Difference in Chitinase (A), Protease (B), and Cellulase $(C)$ activities in compost with various pH and material. Error bars represents standard deviation mean of three replicates while means with the same letters in same observation are not significantly different at 0.05 level of LSD test. $\mathrm{M}=$ Made compost, $\mathrm{C}=$ Made compost, $\mathrm{C}=$ Commercial compost.

Total number of bacteria and chitinase producing bacteria in compost: The total number of bacteria fluctuated in response to the change in $\mathrm{pH}$ and treatment (microbial and fertilizer) in compost. The microorganisms involved in the bioprocess are mainly bacteria which play a vital role in the plant bioassay. Total number of bacteria (TNB) populations and chitinase producing bacteria $(\mathrm{CPB})$ isolated from various

Table 2. Changes in plant leaf area per plant, total number of leaves per plant, and leaf fresh weight and chlorophyll content in various treatments.

\begin{tabular}{lccccc}
\hline Treatment & Shoot Length & $\begin{array}{c}\text { Number of } \\
\text { Leaves }\end{array}$ & Leaf area $(\mathbf{c m})$ & $\begin{array}{c}\text { Leaf } \\
\text { weight }(\mathbf{g})\end{array}$ & $\begin{array}{c}\text { Chlorophyll } \\
\left(\boldsymbol{\mu g} \mathbf{~ c m}^{-2}\right)\end{array}$ \\
\hline pH 4.5 MC & $48.8 \mathrm{~d}$ & $200.0 \mathrm{a}$ & $1386.6 \mathrm{a}$ & $4.2 \mathrm{a}$ & $45.7 \mathrm{a}$ \\
pH4 4.5 MF & $50.5 \mathrm{dc}$ & $184.6 \mathrm{ab}$ & $1470.9 \mathrm{a}$ & $2.9 \mathrm{bc}$ & $42.5 \mathrm{a}$ \\
pH 5.5 MC & $50.6 \mathrm{~d}$ & $116.0 \mathrm{~b}$ & $891.3 \mathrm{ab}$ & $3.7 \mathrm{ba}$ & $41.8 \mathrm{a}$ \\
pH 5.5 MF & $61.2 \mathrm{bac}$ & $56.3 \mathrm{~d}$ & $355.3 \mathrm{~cd}$ & $1.5 \mathrm{~d}$ & $25.3 \mathrm{~d}$ \\
pH 4.5 CC & $50.2 \mathrm{~d}$ & $116.0 \mathrm{bc}$ & $891.1 \mathrm{~b}$ & $3.7 \mathrm{ba}$ & $36.8 \mathrm{ba}$ \\
pH 4.5 CF & $42.6 \mathrm{e}$ & $53.1 \mathrm{~d}$ & $523.7 \mathrm{c}$ & $2.4 \mathrm{c}$ & $32.3 \mathrm{dc}$ \\
pH 7 MC & $70.6 \mathrm{a}$ & $212.3 \mathrm{a}$ & $1388.6 \mathrm{a}$ & $4.3 \mathrm{a}$ & $47.2 \mathrm{a}$ \\
pH 7 MF & $58.6 \mathrm{bdc}$ & $61.4 \mathrm{~d}$ & $434.3 \mathrm{~cd}$ & $2.4 \mathrm{c}$ & $34.5 \mathrm{bc}$ \\
\hline
\end{tabular}

The same letters in same column are not significantly different at 0.05 level of LSD test; $\mathrm{MC}=$ Made compost Culture, $\mathrm{CF}=\mathrm{Made}$ compost Fertilizer, $\mathrm{CC}=$ Commercial compost Culture, $\mathrm{CF}=$ Commercial compost Fertilizer 
compost treatments are illustrated in Figure 4. A significantly higher bacterial population $(\log 10)$ was found in all types of compost with bacterial inoculation. Total bacterial colonies and chitinase producing bacteria was significantly higher with $\mathrm{pH} 7 \mathrm{MC}$ followed by $\mathrm{pH}$ 5.5 MC, pH 5.5 CC and pH 4.5 MC and found high as compare to fertilizer treatment. Lowest total numbers of bacteria were found in $\mathrm{pH} 5.5 \mathrm{CF}$ while lowest chitinase producing bacteria were calculated in $\mathrm{pH} 4.5$ MF.

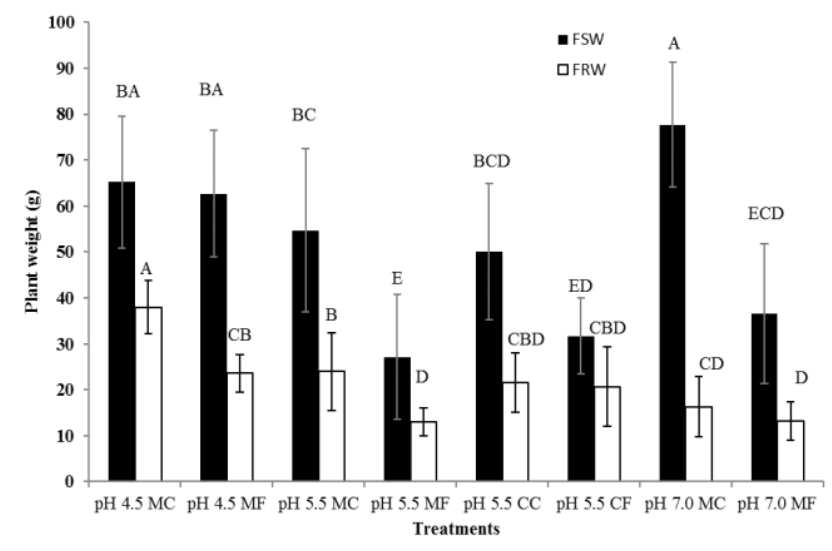

Figure 3. Changes in plant weight calculated as fresh shoot weight (FSW) and fresh root weight (FRW) in various treatments pH 4.5 MC, pH 4.5 MF, pH 5.5 MC, pH 5.5 MF, pH 5.5 CC, pH 5.5 CC, pH 7 MC and pH 7 MC. Error bars represents standard deviation mean of three replicates while means with the same letters in same observation are not significantly different at 0.05 level of LSD test; $\mathrm{MC}=$ Made compost Culture, $\mathrm{CF}=$ Made compost Fertilizer, $\mathrm{CC}=$ Commercial compost Culture, $\mathrm{CF}=$ Commercial compost Fertilizer.

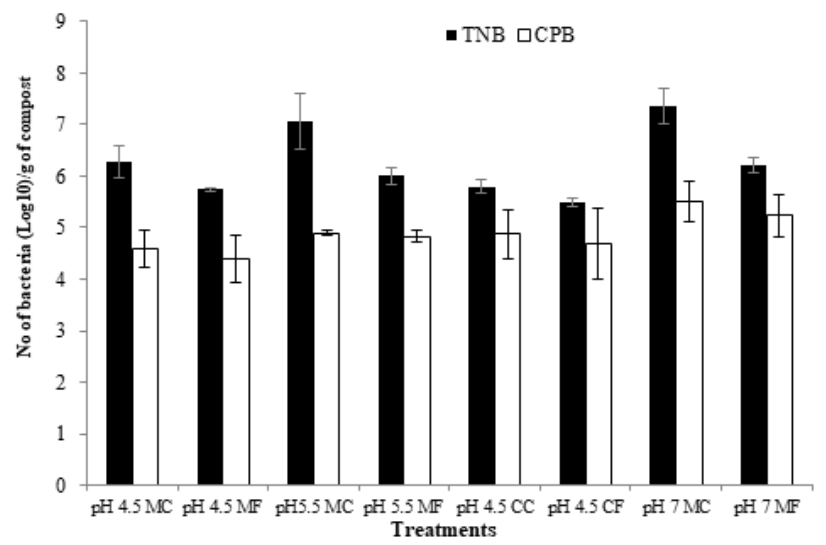

Figure 4. Difference in total number of bacteria (A) and chitinase producing bacteria (B) colonies found in various compost treatments with $\mathrm{pH} 4.5 \mathrm{MC}$, pH 4.5 MF, pH 5.5 MC, pH 5.5 MF, pH 5.5 CC, pH $5.5 \mathrm{CF}$, pH $7 \mathrm{MC}$ and pH $7 \mathrm{MF}$. Error bars represents standard deviation of three replicates $\mathrm{MC}=$
Made compost Culture, $\mathrm{CF}=$ Made compost Fertilizer, $\mathrm{CC}=$ Commercial compost Culture, $\mathrm{CF}=$ Commercial compost Fertilizer.

Chitinase and gelatinase activity in compost: After harvesting plants, $\mathrm{pH} 7 \mathrm{MC}$ treatments has highest chitinase activity followed by $\mathrm{pH} 7 \mathrm{MF}, \mathrm{pH} 5.5 \mathrm{MC}, \mathrm{pH} 5.5 \mathrm{CC}, \mathrm{pH}$ 5.5 CF, pH 5.5 MF, pH 4.5 MC and $\mathrm{pH} 4.5 \mathrm{MF}$ (5 A). Gelatinase activity (unit/g) in compost was also checked at the end of pot experiment and was found with maximum value in $\mathrm{pH} 7 \mathrm{MC}$ highest among all treatment (Fig. 5B). However, all fertilizer treatments were found low with chitinase and gelatinase activity as compare to their respective culture treatment, $\mathrm{pH} 5.5 \mathrm{MF}<\mathrm{pH} 5.5 \mathrm{MC} \mathrm{pH} 5.5 \mathrm{CF}<\mathrm{pH} 5.5 \mathrm{CC}$, and $\mathrm{pH} 4.5 \mathrm{MF}<\mathrm{pH} 4.5 \mathrm{MC}$.
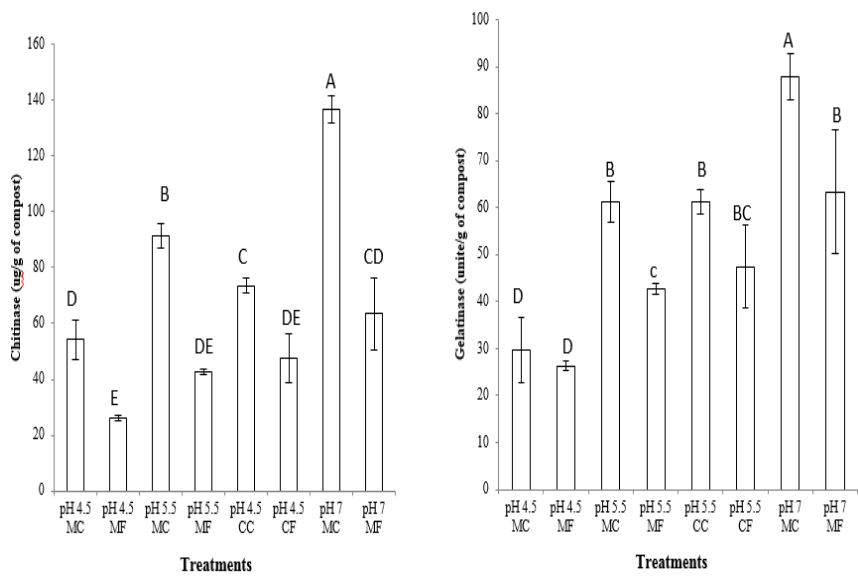

Figure 5. Difference in chitinase (A) and gelatinase (B) activity in various treatments of compost with pH 4.5 MC, pH 4.5 MF, , pH 5.5 MC, pH 5.5 MF, pH 4.5 CC, pH 4.5 CF, pH $7 \mathrm{MC}$ and pH $7 \mathrm{MC}$. Error bars represents standard deviation mean of three replicates while means with the same letters in same observation are not significantly different at 0.05 level of LSD test; $\mathrm{MC}=$ Made compost Culture, $\mathrm{CF}=$ Made compost Fertilizer, $\mathrm{CBT}=$ Commercial compost Before Treatment, $\mathrm{CC}=$ Commercial compost Culture, $\mathrm{CF}=$ Commercial compost Fertilizer

\section{DISCUSSION}

In this study, we formulated compost mainly containing wood crust, peat moss and crab shell powder $(\mathrm{pH} \mathrm{7)}$ to grow blueberry and compared its properties at $\mathrm{pH} 4.5,5.5$ and 7 with commercially available compost ( $\mathrm{pH} 4.5$ ). To compare growth of blueberry at various $\mathrm{pH}$ using five bacteria, we divided our made compost material on the basis of $\mathrm{pH}(4.5$, 5.5 and 7) using $\mathrm{H}_{2} \mathrm{SO}_{4}$. A significant decline in compost $\mathrm{pH}$ was found due to acidification. Decline in compost material $\mathrm{pH}$ due to deposition of $\mathrm{SO}_{2}$ was also reported by Bewley and Parkinson (1984) and Maynard et al. (1986). Our made compost (pH 4.5 M, pH 5.5 M and $\mathrm{pH} 7 \mathrm{M}$ ) was found to have 
more $\mathrm{N}, \mathrm{P}, \mathrm{K}, \mathrm{Ca}, \mathrm{Mg}$ and $\mathrm{S}$ than commercially available compost. In our made compost, decline in organic matter was observed with application of $\mathrm{H}_{2} \mathrm{SO}_{4}$. Previous studies reported that soil acidification leads to changes in the solubility of organic matter (Stroo and Alexander, 1986) and such changes might affect the chemical properties of compost. Phosphorus is also a major nutrient for plants and microorganisms. Along with change in $\mathrm{P}$ level, elements like $\mathrm{K}, \mathrm{Mg}$, and $\mathrm{Ca}$ all were affected by lowering $\mathrm{pH}$. Nutrients concentration containing $\mathrm{P}, \mathrm{Ca}, \mathrm{Mg}, \mathrm{Mn}$ or $\mathrm{Zn}$ can be affected indirectly by high $\mathrm{pH}$ induced by an excess of exchangeable sodium (Abrol et al., 1988). The impact of low $\mathrm{pH}$ on microbial populations was most evident for bacteria, fungi, protozoa and algae.

Bacterial and fungal populations significantly changed due to short- and long-term acidification or $\mathrm{SO}_{2}$ deposition (Bewley and Parkinson, 1985). For soil microbial community, $\mathrm{pH}$ has been proposed as the main factor affecting its biodiversity and richness (Fierer and Jackson, 2006, Lauber et al., 2009), while sulfur is one of the predominant factor for Eh-pH characteristic of natural environment (Becking et al., 1960). Our results indicate the adverse effect of acidification on bacterial population and type of bacteria. The $\mathrm{pH} 7 \mathrm{M}$ has high number of bacterial population compared to $\mathrm{pH} 4.5 \mathrm{M}$, $\mathrm{pH} 5.5 \mathrm{M}$ and $\mathrm{pH} 4.5 \mathrm{C}$. Diversity is highest in neutral soils and minimum in acidic soils (Hinsinger et al., 2009). In our study, there was a significant reduction in populations of chitinase producing bacteria in compost with acidification. Similar decline in heterotrophic microbial activity due to soil acidification has been reported by Bitton and Boylan (1985). Shen et al. (2013) reported that soil pH was predominant factor for the spatial distribution of bacterial communities. Like microbial biomass certain enzymes may predominate at specific soil $\mathrm{pH}$ range. The microbial biomass is the key for production of enzymes, as biomass degraded or declined production of enzymes also decreased (Ayuso et al., 1996). In our observations, enzyme activities clearly reduced, which indicate that application of $\mathrm{H}_{2} \mathrm{SO}_{4}$ caused $\mathrm{pH}$ declined affecting microbial biomass (chitinase producing bacteria) and their enzyme activities in compost. Frankenberger and Dick (1983) reported phosphodiesterase and galactosidase were found to correlate significantly with microbial biomass. Killham and Firestone (1983) reported a reduction in dehydrogenase, urease and arylsulfatase activities due to acid rain.

In our pot experiment, there was significant difference in culture and fertilizer treatment regarding plant biomass including fresh shoot weight, shoot height, number of leaves, leaf area, leaf weight and total chlorophyll in all compost treatments. Our compost (pH 4.5 M, pH 5.5 M and pH $7 \mathrm{M}$ ) showed more growth as compare to commercial compost. The maximum plant biomass was found when plants were treated with bacterial culture at $\mathrm{pH} 4.5$ (MC) and $\mathrm{pH} 7$ (MC). The increase in yield at $\mathrm{pH} 4.5 \mathrm{M}$ is due to optimal $\mathrm{pH}$ as according to previous reports that blueberry plant prefer low $\mathrm{pH}$ for growth (Eck, 1988). An increase in plant shoot weight was significantly correlated with application of bacteria in all treatments. Higher biomass of blueberry may be due to high uptake of some nutrients occurred with application of bacteria compared to fertilizer treatment. These results agree with according to the previous work of de silva et al. (2000), who reported growth promotion of highbush blueberry by fungal and bacterial inoculants. The $\mathrm{pH} 7 \mathrm{MC}$ showed significantly higher biomass compared to $\mathrm{pH} 5.5 \mathrm{M}$ due to optimal $\mathrm{pH}$ for PGPR to compete with natural flora to colonize well and promote plant growth. Though the exact mechanism of growth promotion was not investigated in this study but may be the growth of blueberry promoted due to interaction of inoculated bacteria with plant roots. According to previous studies that many strains of $B$. subtilis, $B$. amyloliquefaciens and $B$. cereus interact with plant and suppress plant pathogens (Choudhary and Johri, 2009), solubilizing nutrients, fixing nitrogen, secreting growth regulators (de-Bashan, 2010), and producing growthregulating substances (Brown and Surgeoner, 1991), siderophores, HCN and lytic enzymes in the rhizosphere resulting plant growth promotion (Aeron et al., 2011). The in vitro and in vivo growth promotion traits of bacteria used in this study were well documented in our previous studies (Nguyen et al., 2013; Kyaw et al., 2014; Lee and Kim, 2015; Jamal et al., 2015).

The bacterial population was found to enhance after harvesting blueberry plants. Mubashir et al. (2016), reported plant growth promotion in wheat using Bacillus sp. MWT-14 and Pseudomonas sp. LYT-1 and found indigenous bacterial population played an important role. In all culture treatments, increased CFU of total bacterial population and chitinase producing bacteria is encountered by the fertilization of blueberry with five bacteria. The increase in rhizosphere bacterial population may be assumed due to inoculated bacteria. This increase in rhizosphere reflects our previous study in which an increase in total bacterial population was observed after inoculation $P$. ehmensis KWN38 in rhizosphere of tomato plants (Kyaw et al., 2014). Our findings are also in agreement with the results of Kim et al. (2008), who reported an increased in chitinolytic bacteria due to addition of growth medium containing chitin. According to previous studies of Chae et al. (2006) and Manjula and Podile (2001), that chitin-containing formulations and addition of chitin-amended compost in soil increased population levels of chitinase producing bacteria in soil. Measurement of soil enzyme activity is known to be important criteria to predict overall microbial activity and microbial population. Hong et al. (2013) reported that addition of P. ehimensis RS820 culture broth containing crab shell powder as chitinous materials in soil increased the number of chitinolytic and gelatinolytic bacteria, along with production of lytic enzymes. In our study, activity of chitinase and gelatinase was found to 
increase with bacterial inoculation in compost. The chitinase activity increased due to crab shell powder in bacteria growing media. This shows that bacteria produce more chitinase using chitin as substrate in compost. This finding is according to our previous study in which addition of bacterial culture and crab shell powder significantly increased chitinase and gelatinase activities along with increased in chitinolytic and gelatinolytic bacteria in rhizosphere (Lee et al., 2015).

Conclusions: In our study, $\mathrm{M}$ compost was found to be more efficient compared to commercial compost as indicated by physiochemical properties and biochemical properties. The application of $\mathrm{H}_{2} \mathrm{SO}_{4}$ has negative effects on biochemical properties as $\mathrm{pH} 4.5 \mathrm{M}$ and $\mathrm{pH} 5.5$ comprising low bacterial biomass and enzyme activities than $\mathrm{pH} 7 \mathrm{M}$ compost. In blueberry pot experiment, the microbial consortium enhanced more plant growth under natural $\mathrm{pH}$ (without application of chemicals) by increasing availability of nutrients for plants. In addition, the rhizosphere of the higher biomass plants was found to have more bacterial biomass and enzyme activities. The application of microorganisms can be helpful to reduce complication of $\mathrm{pH}$ adjustment to grow lowbush blueberry. From our study, it can conclude that our made compost containing wood crust, peat moss and crab shell powder can be used as alternative to commercially available compost mainly contained pine bark and peat moss.

Acknowledgement: This research was supported by IPET (Institute of Planning and Evaluation for Technology in Food, Agriculture, Forestry and Fisheries for which this work was funded under Grant No: 316032-5), Ministry for Food, Agriculture, Forestry and Fisheries, Republic of Korea.

\section{REFERENCES}

Abrol, I., J.S.P. Yadav and F. Massoud. 1988. Salt-affected soils and their management. Food and Agriculture Organization of the United Nations Rome, Italy. Available online at http://eprints.utm.my/31876/4/SaidAbdullahKhalfanMF S2012REF.pdf

Aeron, A., S. Kumar, P. Pandey and D.K. Maheshwari. 2011. Emerging role of plant growth promoting rhizobacteria in agrobiology. In: D.K. Maheshwari (ed.), Crop Ecosystems. Springer Berlin Heidelberg, Germany; pp.136.

Alef, K. and P. Nannipieri. 1995. Methods in applied soil microbiology and biochemistry. In: P. Nannipieri (ed.), Quality Control and Quality Assurance in Applied Soil Microbiology and Biochemistry. Academic Press, USA; pp.5-47.

Atkinson, C.F., D.D. Jones and J.J. Gauthier. 1996. Biodegradability and microbial activities during composting of poultry litter. Poult. Sci. 75:608-617.
Ayuso, M., T. Hernandez, C. Garcia and J. Pascual. 1996. Biochemical and chemical-structural characterization of different organic materials used as manures. Bioresour. Technol. 57:201-207.

Becking, L.B., I.R. Kaplan and D. Moore. 1960. Limits of the natural environment in terms of $\mathrm{pH}$ and oxidationreduction potentials. J. Geol. 68:243-284.

Bewley, R. and D. Parkinson. 1985. Bacterial and fungal activity in sulphur dioxide polluted soils. Can. J. Microbiol. 31:13-15.

Bitton, G. and R.A. Boylan. 1985. Effect of acid precipitation on soil microbial activity: I. Soil core studies. J. Environ. Qual. 4:66-69.

Brown, A.E. and R. Surgeoner. 1991. Enhancement of plant growth by Zygorrhynchus moelleri. Ann. Appl. Boil. 118:39-46.

Choudhary, D.K. and B.N. Johri. 2009. Interactions of Bacillus spp. and plants with special reference to induced systemic resistance (ISR). Microbiol. Res. 164:493-513.

de-Bashan, L.E. and Y. Bashan. 2010. Immobilized microalgae for removing pollutants: Review of practical aspects. Bioresour. Technol. 101:1611-1627.

Eck, P. 1988. Blueberry Science. Rutgers University Press, Brunswick.

Eck, P. and N.F. Childers. 1966. The blueberry industry. In: N.F. Childers (eds.), Blueberry Culture. Rutgers University Press, New Brunswick, NJ; pp.3-13.

Fierer, N. and R.B. Jackson. 2006. The diversity and biogeography of soil bacterial communities. Proc. Natl. Acad. Sci. 103:626-631.

Frankenberger, W. and W. Dick. 1983. Relationships between enzyme activities and microbial growth and activity indices in soil. Soil Sci. Soc. Am. J. 47:945-951.

Garcia, C., T. Hernandez, F. Costa, B. Ceccanti and C. Ciardi. 1992. Changes in ATP content, enzyme activity and inorganic nitrogen species during composting of organic wastes. Can. J. Soil Sci. 72:243-253.

Godden, B., M. Penninckx, A. Piérard and R. Lannoye. 1983. Evolution of enzyme activities and microbial populations during composting of cattle manure. Appl. Microbiol. Biotechnol. 17:306-310.

Hinsinger, P., A.G. Bengough, D. Vetterlein and I.M. Young. 2009. Rhizosphere: Biophysics, biogeochemistry and ecological relevance. Plant and soil 321:117-152.

Hong, S.H., M. Anees and K.Y. Kim. 2013. Biocontrol of Meloidogyne incognita inciting disease in tomato by using a mixed compost inoculated with Paenibacillus ehimensis RS820. Biocontrol. Sci. Technol. 23:10241039.

Kapoor, M. and R. Rajagopal. 2011. Enzymatic bioremediation of organophosphorus insecticides by recombinant organophosphorous hydrolase. Int. Biodeterior. Biodegrad. 65:896-901. 
Killham, K.A. and M. Firestone. 1983. Vesicular arbuscular mycorrhizal mediation of grass response to acidic and heavy metal depositions. Plant and Soil 72:39-48.

Kim, Y.C., H. Jung, K.Y. Kim and S.K. Park. 2008. An effective biocontrol bioformulation against phytophthora blight of pepper using growth mixtures of combined chitinolytic bacteria under different field conditions. Eur. J. For. Res. 120:373-382.

Kumar, V. and N. Narula. 1999. Solubilization of inorganic phosphates and growth emergence of wheat as affected by Azotobacter chroococcum mutants. Biol. Ferti. Soils 28:301-305.

Lauber, C.L., M. Hamady, R. Knight and N. Fierer. 2009. Pyrosequencing-based assessment of soil $\mathrm{pH}$ as a predictor of soil bacterial community structure at the continental scale. Appl. Environ. Microbiol. 75:51115120.

Lee, Y.S., X.H. Nguyen, K.W. Naing, Y.S. Park and K.Y. Kim. 2015. Role of lytic enzymes secreted by Lysobacter capsici YS1215 in the control of root-knot nematode of tomato plants. Ind. J. Microbiol. 55:74-80.

Naing, K.W., M. Anees, X.H. Nguyen, Y.S. Lee, S.W. Jeon, S.J. Kim, M.H. Kim and K.Y. Kim. 2014. Biocontrol of late blight disease (Phytophthora capsici) of pepper and the plant growth promotion by Paenibacillus ehimensis KWN38. J. Fitopatologi 162:367-376.

Nguyen, X.H., K.W. Naing, Y.S. Lee, W.J. Jung, M. Anees and K.Y. Kim. 2013. Antagonistic potential of Paenibacillus elgii HOA73 against the root-knot nematode, Meloidogyne incognita. Nematology 15:9911000 .
Pritts, M.P. and J.F. Hancock. 1992. Highbush blueberry production guide. North-east Agricultural Engineering Service, Ithaca, NY, USA; p.200.

Probanza, A., J.L. Garcia, M.R. Palomino, B. Ramos and F.G. Mañero. 2002. Pinus pinea L. seedling growth and bacterial rhizosphere structure after inoculation with PGPR Bacillus (B. licheniformis CECT 5106 and $B$. pumilus CECT 5105). Appl. Soil Ecol. 20:75-84.

Puente, M., C. Li and Y. Bashan. 2004. Microbial populations and activities in the rhizoplane of rock-weathering desert plants. II. Growth promotion of cactus seedlings. Plant Biol. 6:643-650.

Strik, B.C. and D. Yarborough. 2005. Blueberry production trends in North America, 1992 to 2003, and predictions for growth. HortTechnol. 15:391-398.

Tiquia, S.M., H. Wan and N.F. Tam. 2002. Microbial population dynamics and enzyme activities during composting. Compost. Sci. Util. 10:150-161.

Vuorinen, A.H. 2000. Effect of the bulking agent on acid and alkaline phosphomonoesterase and $\beta$-D-glucosidase activities during manure composting. Bioresour. Technol. 75:133-138.

Wong, J., S. Li and M. Wong. 1995. Coal fly ash as a composting material for sewage sludge: Effects on microbial activities. Environ. Technol. 16:527-537.

Yadav, K. and K. Dadarwal. 1997. Phosphate solubilization and mobilization through soil microorganism. In: K.R. Dadarwal (ed.), Biotechnological Approaches in Soil Microorganisms for Sustainable Crop Production. Scientific Publishers, India; pp.293-308. 